\title{
The Effect of Arbuscular Mycorrhizal Fungi and Gliocladium Fungi on the Yield of Small Green Pepper (Capsicum annuum) Grown by Sustainable Agriculture
}

\author{
Mohammed Zahidul Islam, Sadanobu Katoh* \\ Interdisciplinary Graduate School of Science and Engineering, Shimane University, Matsue, Japan \\ Email: *sadanobu@riko.shimane-u.ac.jp
}

How to cite this paper: Islam, M.Z. and Katoh, S. (2017) The Effect of Arbuscular Mycorrhizal Fungi and Gliocladium Fungi on the Yield of Small Green Pepper (Capsicum annuum) Grown by Sustainable Agriculture. Agricultural Sciences, 8, 1296-1314.

https://doi.org/10.4236/as.2017.811094

Received: October 25, 2017

Accepted: November 26, 2017

Published: November 29, 2017

Copyright $\odot 2017$ by authors and Scientific Research Publishing Inc. This work is licensed under the Creative Commons Attribution International License (CC BY 4.0).

http://creativecommons.org/licenses/by/4.0/

\begin{abstract}
The potential vulnerability of the conventional agricultural systems has been become increasingly alarmed for agricultural scientists, government officials, environmentalists, farmers (both urban and rural laymen). Agricultural soils are often subject to loss of carbon, toxicity and hazard of agrochemicals, nutrient run-off, excessive erosion, and consequently a decline in soil fertility. The purpose of this study is to present new perspectives and strategies for efficient and effective use of natural resources (wood and bamboo wastes, weeds, and fungi) to enhance sustainable systems of agriculture. A next generation agriculture by using wood and bamboo wastes with the application of arbuscular mycorrhizal fungi (AMF) and gliocladium fungi (GF) was investigated to establish high productivity of small green pepper (SGP, Capsicum annuum). Wood and bamboo wastes as carbon sources, cut weeds as organic sources, and a minor amount of AMF, and GF were applied separately and conjointly in the four experimental plots to evaluate the effects of wood and bamboo wastes (high C:N ratio), weeds, and fungi on the production of SGP. The combination of carbon, organic, and fungal sources at $\mathrm{T}_{1}$ (wood wastes + bamboo wastes + cut weeds + AMF + GF) obtained high productivity of SGP. The yield was 400 times higher than control (untreated). Another notable significant result is that all the treatments contained a very small amount of nitrate compared to conventional practice. This study suggests that combination of carbon (wood, and bamboo wastes), organic (cut weeds), and fungal sources (AMF, and GF) has a potential to be innovative agricultural materials for the next generation sustainable agriculture.
\end{abstract}

\section{Keywords}

Wood Waste, Bamboo Waste, Arbuscular Mycorrhizal Fungi, Agriculture, 
Sustainability

\section{Introduction}

Worldwide indiscriminate use of agro-chemicals boosts agricultural productivity since the green revolution of 1960s, with the cost of the environment and society. It kills the valuable soil microorganisms and destroys their natural fertility, and reduces the power of biological resistance in crops to make them more susceptible to pests and diseases [1] [2] [3]. The scientific community all over the world is urgently searching for an "economically viable, socially safe and environmentally sustainable" alternative to the poisonous agro-chemicals [4]. The U.S. National Research Council (1989) defined sustainable agriculture as "those alternative farming systems and technologies incorporating natural processes, reducing the use of inputs of off-farm sources, ensuring the long term sustainability of current production levels and conserving soil, water, energy, and farm biodiversity" [5]. It is a method of agricultural production, which avoids or largely omits the application of systematically compounded chemical fertilizers and pesticides and promises the utilization of environmentally amicable organic inputs.

By 2050, the world's population will reach 9.1 billion, 34 percent higher than today [6]. Global demand for agricultural crops definitely emphasizes the necessity to implement eco-friendly agricultural management practices for sustainable agricultural production. It is not adequate to produce sufficient food to feed the civilization, but to engender a high quality of nutritive food which should be safe (chemical free) and protective to human health and the environment, and to engender it in a sustainable manner to deserve food security for all. The difficulties are associated with the consumption of poisonous chemicals, because crop protection, weed control, and soil fertility are getting increasing attention worldwide since pests, diseases, and weeds become resistant to chemical pesticides and environmental pollution and ecological imbalances may occur. So, the engenderment of organic agriculture products without inputs of chemical pesticides and synthetic fertilizers has become more concerned [4] [7]-[12].

Numerous researchers have emphasized that organic firming must be reinstated as a sustainable agricultural system that minimizes the global environmental impacts [13]. However, many reports have concluded that the yields of organic agriculture are typically lower than those of conventional agriculture. Organic farming would therefore need more land to produce the same amount of food as conventional agriculture resulting in adverse environmental impact [14] [15] [16].

Recently, a promising agricultural approach for utilizing wood wastes has been reported that application of a high carbon:nitrogen (C:N) ratio organic material without additional nitrogen fertilizer achieved four times higher productivity than that of conventional farms [17]. The new approach using a high $\mathrm{C}: \mathrm{N}$ ratio organic material such as wood and bamboo wastes supplies high 
amount of carbon to various fungi, and fungi perform important functions in the soil in relation to nutrient cycling, disease suppression, and water dynamics, all of which help plants become healthier and more vigorous. Moreover, fungi can promote soil aggregation [18], the aggregate soil structures, which possess high air and water permeability and water holding capacity, provide essential functions for plants and microorganisms, including fungi and bacterial symbionts, and consequently give faster plant growth and high productivity. This condition is also suitable for preventing plant diseases and insect infestation of plants because constructed soil biodiversity does not allow exclusive propagations of specific pathogens and pests. Furthermore, it contributes greatly to the mitigation of greenhouse gas, since $\mathrm{CO}_{2}$ emission in the composting process can be largely reduced. Accordingly, this new approach is able to achieve higher productivity without adverse environmental impact and without the cultivation of more land, which is called sustainable intensification [19].

Wood grows naturally, and it is renewable resource. The objective of this study is to present new directions and approaches for effective use of wood and bamboo wastes, weeds, and fungi to develop sustainable systems of agriculture. Large volumes of wood wastes are generated in many ways. Sawdust, chips, planer shavings, bark, slabs, end trims, sander dust, used or scrapped pallets, logs, brush, and branches are very common wood wastes. Every year, approximately 8 million tons of wood wastes are engendered in Japan [20]. Bamboo generates large volumes of wastes, and these wastes are excreted from construction, demolition, furniture and any other way. Felicitous management of wood and bamboo wastes should be established as quickly as possible to use wood and bamboo materials properly.

To address the innovative agricultural approach, application efficiencies of carbon (wood, and bamboo wastes), organic (cut weeds), and fungal sources on small green pepper (SGP, Capsicum annuum) production were investigated.

\section{Material and Methods}

\subsection{Experimental Site}

The experiment was carried out in the experimental field of Shimane University, Matsue, Shimane, during the period from $21^{\text {st }}$ April 2015 to $27^{\text {th }}$ November 2015 to assess the integrated effect of carbon, organic, and fungal sources on the growth, yield, and minerals of SGP. Geographically, the site was located between $35^{\circ} 28^{\prime} 27^{\prime \prime} \mathrm{N}$ and $133^{\circ} 3^{\prime} 11^{\prime \prime} \mathrm{E}$. The average temperature, precipitation (rainfall), and relative humidity were $12.5^{\circ} \mathrm{C}$ to $26.5^{\circ} \mathrm{C}, 140 \mathrm{~mm}$ to $280 \mathrm{~mm}$, and $70 \%$ $80 \%$, respectively, from April to November. The soil type of the experimental area was sandy loam with soil $\mathrm{pH}$ of 6.0.

\subsection{Land Preparation, Experimental Design, and Treatment Combination}

The experimental field was cleared, ploughed, harrowed and divided into 4 plots, 


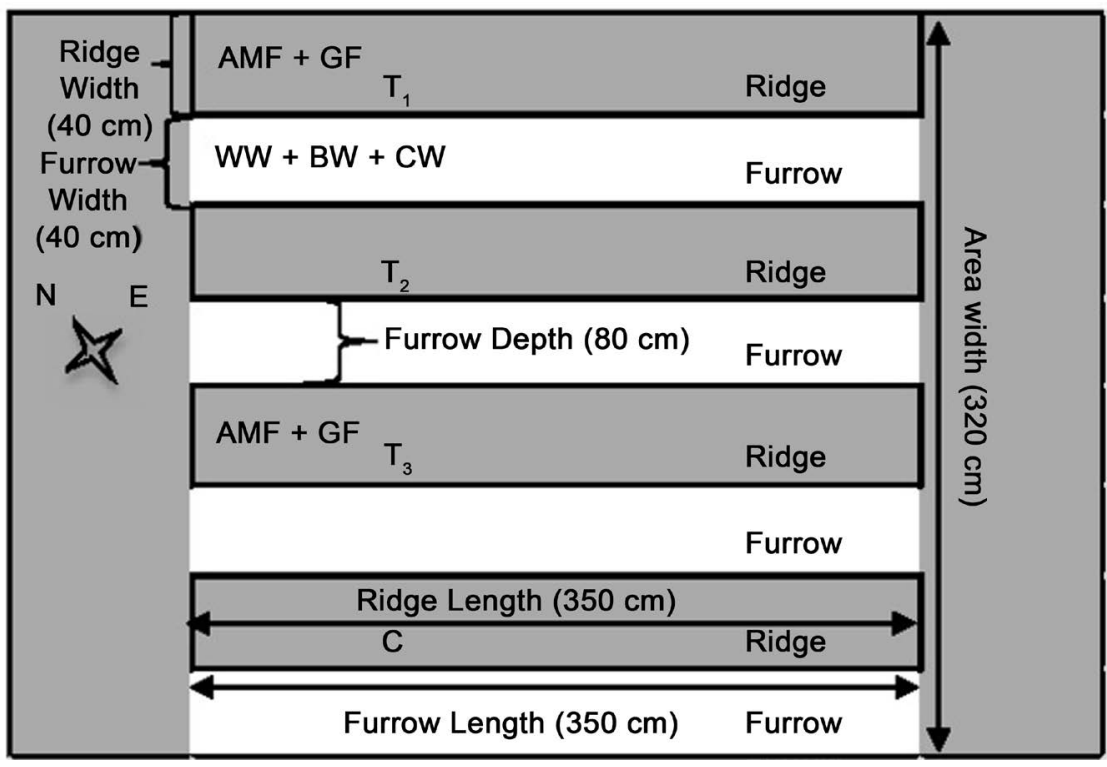

Notes: $\mathrm{WW}=$ Wood wastes, $\mathrm{BW}=$ Bamboo wastes, $\mathrm{CW}=$ Cut weeds (meadow grass, couch grass, horsetail, nettle, chickweed, ground elder, etc.), AMF = Arbuscular mycorrhizal fungi, GF = Gliocladium fungi (Gliocladium sp.).

Figure 1. Layout of the experimental site.

with $11.20 \mathrm{~m}^{2}$ areas. 3 treated and 1 control plots were prepared. Each plot site contained 1 ridge $(1$ ridge $=350 \mathrm{~cm}$ length $\times 40 \mathrm{~cm}$ width $\times 20 \mathrm{~cm}$ height $)$ and 1 furrow ( 1 furrow $=350 \mathrm{~cm}$ length $\times 40 \mathrm{~cm}$ width $\times 80 \mathrm{~cm}$ depth), plot area is presented in Figure 1.

Wood wastes, bamboo wastes, cut weeds, arbuscular mycorrhizal fungi (AMF), and gliocladium fungi (GF) were applied as agricultural materials. The experimental design was laid out in a completely randomized design with 3 treatments namely, $\mathrm{T}_{1}$ - wood wastes + bamboo wastes + cut weeds (meadow grass, couch grass, horsetail, nettle, chickweed, ground elder, etc.) + AMF (Idemitsu) + GF (Idemitsu), $\mathrm{T}_{2}$ - wood wastes + bamboo wastes + cut weeds, $\mathrm{T}_{3}-$ AMF + GF, C-control. Wood wastes $\left(0.40 \mathrm{~m}^{3} /\right.$ furrow), bamboo wastes $(0.40$ $\mathrm{m}^{3} /$ furrow), weeds $\left(0.25 \mathrm{~m}^{3} /\right.$ furrow), AMF and GF ( $\left.5 \mathrm{mg} / \mathrm{plant}\right)$ were directly used in the ridges and furrows for the experimental investigation.

\subsection{Plant Material}

In the present work, SGP was considered as plant material. Commercially available seedlings were used for the experimental observation, 4 plants were transplanted in each treatment and average plant height was $15 \mathrm{~cm}$ at transplanting time.

\subsection{Test Crop Establishment and Management}

\subsubsection{Application of Agricultural Material}

Experimental investigations were conducted with three elements as carbon (wood, and bamboo wastes), organic (cut weeds), and fungal (AMF, and GF) 
sources. Conventional agro materials such as chemical fertilizers, microelements, growth promoters, $\mathrm{pH}$ control chemicals, or other agricultural chemicals were not used. The loss of carbon from agricultural soil is a critical issue in conventional agriculture. Fertilizer input generally increases net primary production but does not increase soil carbon content. Thus, the major agricultural component was wood and bamboo wastes (high C:N ratio). Root, branch, bark, and log of chinaberry (Melia azedarach) tree as wood wastes, and stem of bamboo as bamboo wastes were used in the two furrows. Bamboo wastes were generated from demolition work, and wood wastes were collected from fallen tree trunk in the experimental area.

\subsubsection{Weed Control}

To minimize soil disturbance, weeds were cut by sickle and put in the furrow when they began to race with crops.

\subsubsection{Pests and Diseases}

Integrated pest management or other conventional methods were not used; only the natural defense system was approached to control pests and diseases.

\subsubsection{Irrigation}

SGP plant generally requires frequent irrigation, but irrigation was continued for only 1 week from the transplanting day during the whole life cycle of SGP.

\subsection{Data Collection and Sampling}

\subsubsection{Yield and Vegetative Growth}

SGP was collected 28 times, from $73^{\text {th }}$ day to $220^{\text {th }}$ day after transplantation, and yield was calculated based on the plot area, and converted the average yield into $\mathrm{kg} / \mathrm{m}^{2}$. Area of each plot was $2.8 \mathrm{~m}^{2}$ (area of one furrow + area of one ridge). Shoot length $(\mathrm{cm})$, and stem diameter $(\mathrm{cm})$ were measured at $100^{\text {th }}$ day and $220^{\text {th }}$ day, respectively.

\subsubsection{Soil Mineral Analysis}

Soil minerals $\mathrm{NO}_{3}^{-}, \mathrm{K}^{+}$, and $\mathrm{Ca}^{2+}(\mathrm{mg} / \mathrm{L})$ were measured by LAQUA (HORIBA) and RQ flex plus 10 (MERCK). $\mathrm{NO}_{3}^{-}, \mathrm{K}^{+}$, and $\mathrm{Ca}^{2+}(\mathrm{mg} / \mathrm{L})$ values were converted into $\mathrm{N}, \mathrm{P}$, and $\mathrm{K}(\mathrm{mg} / 100 \mathrm{~g})$. Soil minerals were measured 4 times in the last 8 months before the transplanting date and 4 times in the next 8 months after the transplanting date of SGP. Every time soil samples were collected from five different places of each treatment, and soil samples of all treatments and control were air-dried for 30 minutes at $105^{\circ} \mathrm{C}$. The LAQUA twin Nitrate Ion meter was used to measure $\mathrm{NO}_{3}^{-}$concentration in soil samples. Soil extract was prepared by mixing soil samples and distilled water (1:6), shaken for 1 minute, and centrifuged for 1 minute. LAQUA twin Nitrate Ion meter was calibrated by the standard solution, and $500 \mu \mathrm{l}$ of soil extract was taken and placed into the sensor. $\mathrm{NO}_{3}^{-}$reading was recorded from the extract solution. RQ flex plus 10 (MERCK) was used to measure $\mathrm{PO}_{4}^{3-}$ concentration in soil samples. Soil ex- 
tract was prepared by mixing $1 \mathrm{~g}$ soil sample and $50 \mathrm{ml}$ of $1 \mathrm{mmol} / \mathrm{L} \mathrm{H}_{2} \mathrm{SO}_{4}$, shaken for 30 seconds, and centrifuged for 2 minutes. Filter paper and funnel were used for filtration. RQ flex plus 10 (MERCK) was calibrated by the standard solution and measured $\mathrm{PO}_{4}^{3-}$ concentration of the filtrated solution. The LAQUA twin Potassium Ion meter was used to measure $\mathrm{K}^{+}$concentration in soil samples. Soil extract was prepared by mixing $1 \mathrm{~g}$ of air-dried soil and $20 \mathrm{ml}$ of $0.01 \mathrm{~mol} / \mathrm{L}$ ammonium acetate, shaken for 1 hour to extract $\mathrm{K}^{+}$from the soil. LAQUA twin Potassium Ion meter was calibrated by the standard solution, and $500 \mu \mathrm{l}$ of soil extract was taken and placed into the sensor. $\mathrm{K}^{+}$reading was recorded from the extract solution.

\subsubsection{SGP Mineral Analysis}

SGP minerals $\mathrm{NO}_{3}^{-}, \mathrm{K}^{+}$, and $\mathrm{Ca}^{2+}(\mathrm{mg} / \mathrm{L})$ were measured by Quantofix (MN) and LAQUA (HORIBA). Minerals were measured 3 times. Conventionally grown SGP was collected from 3 different retail stores, and used for mineral analysis and comparative study with experimental field SGP. Each time SGPs were collected from treatments and control plants, and SGPs were blended to take the juice for mineral analysis. Quantofix $(\mathrm{MN})$ was used to measure $\mathrm{NO}_{3}^{-}$ concentration in SGP samples. It was a nitrite test strip. It measured $\mathrm{NO}_{3}^{-}$ concentration from 0 to $500 \mathrm{mg} / \mathrm{L}$. The LAQUA twin Potassium Ion meter was used to measure $\mathrm{K}^{+}$concentration and LAQUA twin calcium Ion meter was used to measure $\mathrm{Ca}^{2+}$ concentration in SGP's juice samples. LAQUA meter was calibrated by the standard solution, and $500 \mu \mathrm{l}$ of SGP sample was taken and placed into the sensor. $\mathrm{K}^{+}$, and $\mathrm{Ca}^{2+}$ readings were recorded from the SGP samples.

\subsubsection{Observation of AMF}

Arbuscular mycorrhizal (AM) colonization in SGP root was observed with a compound microscope. $10 \% \mathrm{KOH}, 1 \mathrm{~mol} / \mathrm{L} \mathrm{HCl}$, Trypan blue were used for staining the AMF [21]. Root samples were collected and cut at the size of $1 \mathrm{~cm}$. $500 \mu \mathrm{l}$ of $10 \% \mathrm{KOH}$ was added with root samples and then incubated at $95^{\circ} \mathrm{C}$ for 15 minutes. $750 \mu \mathrm{l}$ of $1 \mathrm{~mol} / \mathrm{L} \mathrm{HCl}$ was added with root samples and discarded the solution. Roots were rinsed several times with tap water and then discarded the water. Two drops of trypan blue were added with root samples and incubated at $95^{\circ} \mathrm{C}$ for 10 minutes. Root samples were rinsed by lactoglycerol for 2 days and then observed AMF with a compound microscope.

\subsection{Statistical Analysis}

The experiment was conducted with four replications per treatment and data were conveyed as Mean \pm Standard Error. Statistical analyses of the data were carried out using SPSS software (IBM Corp. Released 2011. IBM SPSS Statistics for Windows, Version 20.0. Armonk, NY: IBM Corp.). The level of significance was calculated from the F value of ANOVA. Mean comparison was achieved by Tukey-test $(P \leq 0.01)$. 


\section{Results}

\subsection{Effect of Different Treatments on the Yield of SGP}

There was statistically significant difference between treatments $\left(\mathrm{T}_{1}\right.$, and $\left.\mathrm{T}_{2}\right)$ and control (Figure 2). Average yield $\left(\mathrm{kg} / \mathrm{m}^{2}\right)$ of different treatments was in the order as follows: $\mathrm{T}_{1}(1.220)>\mathrm{T}_{2}(0.290)>\mathrm{C}(0.003)>\mathrm{T}_{3}(0.001)$. The highest yield was obtained at $T_{1}$ (wood wastes + bamboo wastes + cut weeds + AMF + GF), which was, approximately, 400 times higher than control (C), 4 times higher than $\mathrm{T}_{2}, 1200$ times higher than $\mathrm{T}_{3}$. The average plant yield did not show significant difference at $\mathrm{T}_{3}$, and $\mathrm{C}$. Based on the result, noticeable yield of $\mathrm{T}_{1}$ was influenced by AMF and GF, the application of carbon, organic, and fungal sources increased significantly SGP yield of $T_{1}$, and $T_{2}$. Several researchers revealed that the AMF have a direct effect on the plant productivity and sustainability [22].

\subsection{Effect of Different Treatments on Growth Performance}

\subsubsection{Shoot Length}

Shoot length is one of the most important parameters to measure plant growth. The experimental results clearly indicate that shoot length was significantly high at $\mathrm{T}_{1}$. Combined application of carbon, organic and fungal sources had significant effects on shoot length. Average shoot length $(\mathrm{cm})$ for different treatments was in the order as follows: $T_{1}(59.00)>T_{2}(43.25)>T_{3}(20.00)>C(17.25)$ (Figure 3). The average shoot length did not show significant difference at $\mathrm{T}_{3}$ and C. AMF have been reported to produce plant growth hormones that have beneficial effects on plant growth [23]. Several researchers have shown that AMF improve plant rooting and establishment, enhance vegetative growth, and accelerate budding and flowering [24].

\subsubsection{Stem Diameter}

Combined application of carbon, organic and fungal sources had significant effects on stem diameter. The stem diameter $(\mathrm{cm})$ of SGP plant was in the order:

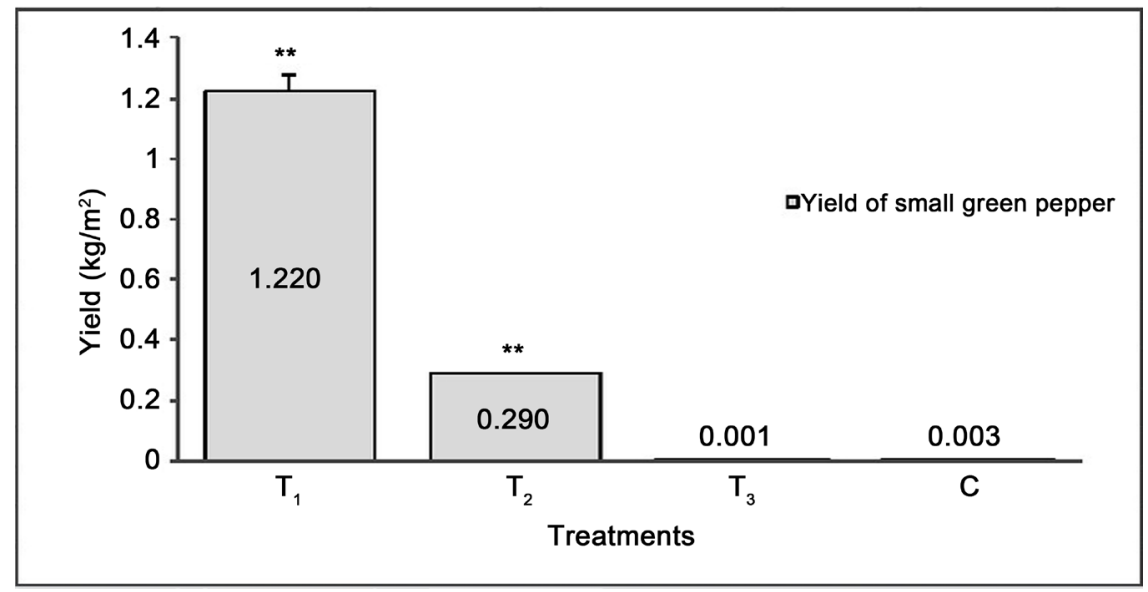

Figure 2. The effect of different treatments on the yield $\left(\mathrm{kg} / \mathrm{m}^{2}\right)$ of small green pepper. Significant differences are indicated by asterisks $\left({ }^{\star *} P<0.01\right)$, vertical lines represent SE. 


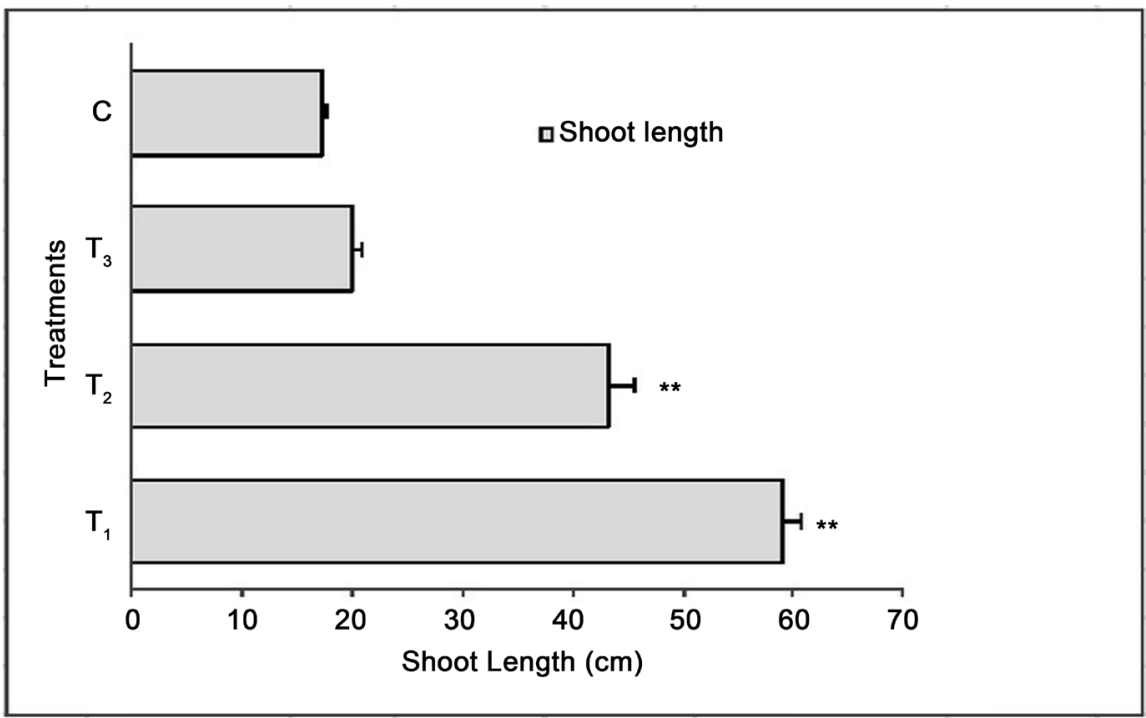

Figure 3. The effect of different treatments on the shoot length $(\mathrm{cm})$ of small green pepper plant. Significant differences are indicated by asterisks $\left({ }^{*} P<0.01\right)$, horizontal lines represent SE.

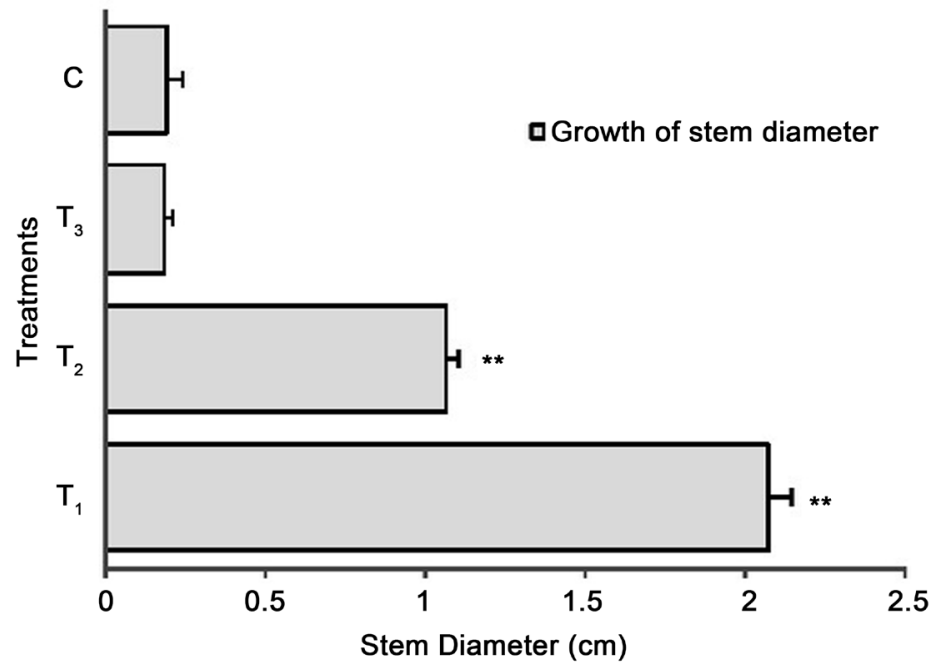

Figure 4. The effect of different treatments on the growth of stem diameter $(\mathrm{cm})$ of small green pepper plant. Significant differences are indicated by asterisks $\left({ }^{* *} P<0.01\right)$, horizontal lines represent SE.

$\mathrm{T}_{1}(2.00)>\mathrm{T}_{2}(1.02)>\mathrm{C}(0.26)>\mathrm{T}_{3}(0.25)$ (Figure 4). The average stem diameter did not show significant difference at $\mathrm{T}_{3}$ and $\mathrm{C}$. The application of carbon, organic, and fungal sources increased significantly the stem diameter of SGP plant.

\subsection{Changes in Soil Mineral Concentration}

Soil mineral nutrients play a vital role in soil fertility. Sixteen minerals are essen- 
tial for plant growth and reproduction. Mineral nutrients required for plants to complete their life cycle are considered as essential nutrients. Nitrogen $(\mathrm{N})$, phosphorus $(\mathrm{P})$, and potassium $(\mathrm{K})$ are essential plant nutrients. These mineral concentrations of soil were significantly influenced by different treatments. Soil mineral concentration gradually increased after passing of a certain time of SGP transplants (Figure 5). Average mineral (N, P, and $\mathrm{K})$ concentrations of different treatments were in the order: $\mathrm{C}>\mathrm{T}_{1}>\mathrm{T}_{2}>\mathrm{T}_{3}, \mathrm{~T}_{1}>\mathrm{T}_{2}>\mathrm{T}_{3}>\mathrm{C}$, and $\mathrm{C}>\mathrm{T}_{3}>$ $\mathrm{T}_{2}>\mathrm{T}_{1}$, respectively in the last 8 months before the transplanting date $\left(21^{\text {st }}\right.$ April 2015) of SGP. However, soil mineral (N, P, and K) concentrations in the next 8 months after the transplanting date of SGP were in the order: $\mathrm{T}_{1}>\mathrm{T}_{2}>\mathrm{C}>\mathrm{T}_{3}$, $\mathrm{T}_{1}>\mathrm{T}_{2}>\mathrm{T}_{3}>\mathrm{C}$, and $\mathrm{T}_{1}>\mathrm{C}>\mathrm{T}_{2}>\mathrm{T}_{3}$, respectively. The highest concentration of $\mathrm{N}, \mathrm{P}$, and $\mathrm{K}$ was observed at the last month (November 2015) of harvesting stage; it was $6.8,16.3$, and $26.7 \mathrm{mg} / 100 \mathrm{~g}$, respectively, at $\mathrm{T}_{1}$. The application of minor amount of AMF and GF raised a large AMF community in the soil of $\mathrm{T}_{1}$, which increased mineral $(\mathrm{N}, \mathrm{P}$, and $\mathrm{K})$ concentrations of $\mathrm{T}_{1}$ soil at the last month of harvesting stage. Several researchers have shown that the AMF colonize in the dead leaves [25] [26], and they are involved in the closure of nutrient cycles in nutrient-poor ecosystems, and have a direct effect on the ecosystem, as they improve the soil structure and aggregation [27] [28] [29], and increase nutrient uptake [23]. AMF absorb N, P, K, Ca, S, Fe, Mn, Cu, and $\mathrm{Zn}$ from the soil and then translocate these nutrients to the plants with whose roots they are associated [30] [31] [32] [33]. Their most consistent and important nutritional effect is to improve uptake of immobile nutrients such as $\mathrm{P}, \mathrm{Cu}$, and $\mathrm{Zn}$ [34] [35].

\subsection{AMF Colonization in Roots}

AMF are the most common soil microorganisms in natural and agricultural soils [36]. Compound microscope was used to visualize the colonization of AMF; this

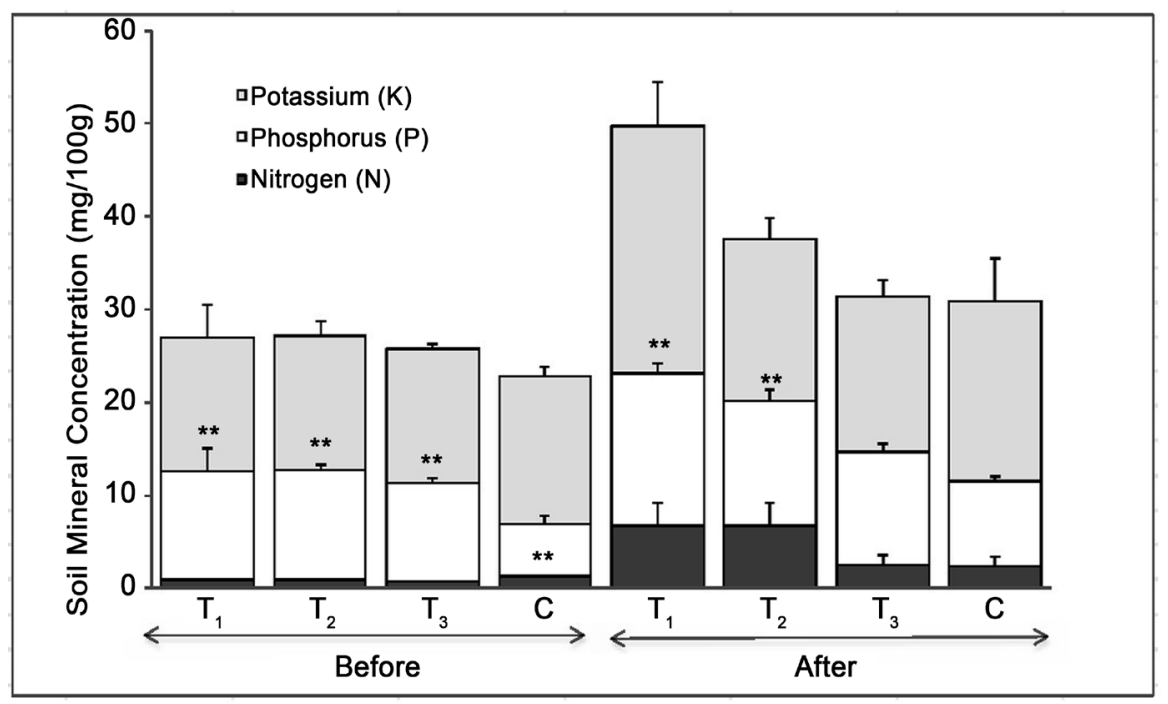

Figure 5. The effect of different treatments on N, P, and K levels of soil. Significant differences are indicated by asterisks $\left({ }^{* *} P<0.01\right)$, vertical lines represent $\mathrm{SE}$. 


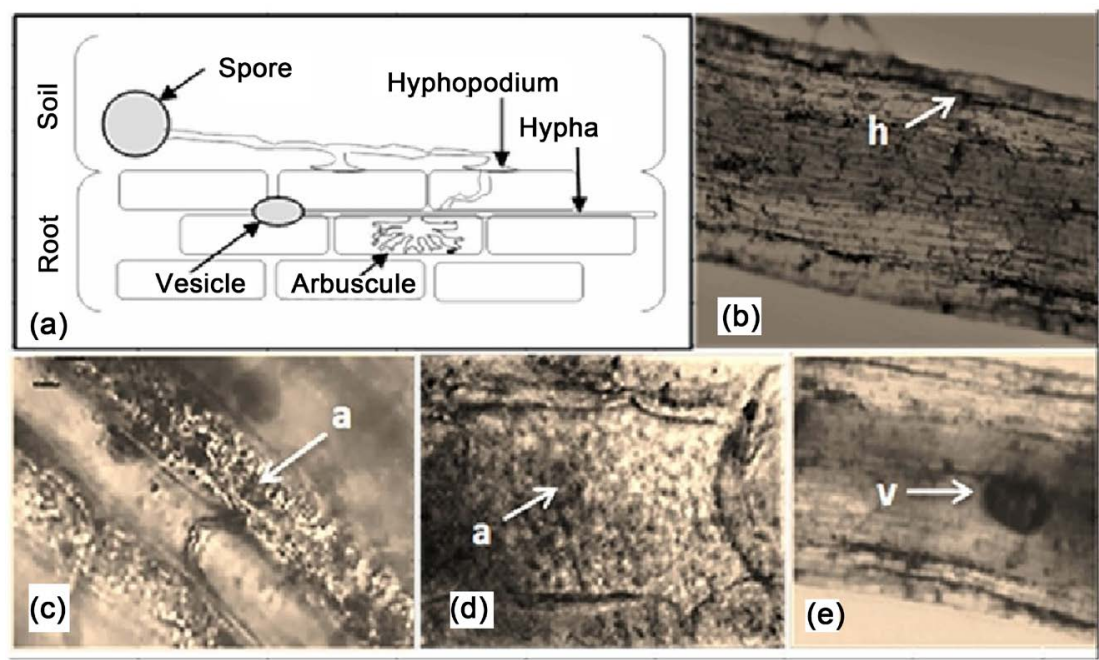

Figure 6. Roots in longitudinal view; all roots were stained with trypan blue and viewed with white light. (a) Process of colonization. Arbuscular spores germinate and hyphae grow towards the root after perception of strigolactones, the fungus forms hyphopodia on the root surface and invades the plant via rhizodermal cells, the hyphae enter the apoplast when they reach in the root cortex and form arbuscules inside inner cortical cells, vesicles are formed inside the apoplast [42]. (b) Capsicum annuum root cortex was colonized by AM hyphae. (c) and (d): Arbuscules. (e): Vesicle. a: arbuscule, h: hypha, v: vesicle.

type of colonization was only involved in inter- and intra-cellularly in cortical cells of roots at $\mathrm{T}_{1}$, and $\mathrm{T}_{2}$. In these cortical cells of roots, vesicles (Figure 6(e)), arbuscules (Figure 6(c), and Figure 6(d)), and hyphae (Figure 6(b)) were observed frequently. AM hyphae colonized in the root cortex at $T_{1}$ and $T_{2}$, and formed highly branched bush-like structures (Figure 6(a), Figure 6(c), and Figure 6(d)) within the host cells. Several types of mycorrhizal associations have been found in the plant kingdom geographically, and the endomycorrhizal association of the AM type is the most widespread [37]. Mycorrhizal associations provide many benefits to the host plant, such as, increase fixation of soil nutrients, mainly $\mathrm{N}$ and $\mathrm{P}$ [38] [39], decrease biotic and abiotic stresses, increase photosynthetic rate [40], and influence chemical defenses [41].

AMF represent a key link between plants and soil mineral nutrients at $\mathrm{T}_{1}$ (wood wastes + bamboo wastes + cut weeds $+\mathrm{AMF}+\mathrm{GF}$ ), and $\mathrm{T}_{2}$ (wood wastes + bamboo wastes + cut weeds). AMF spread to a large area from the soil of $\mathrm{T}_{1}$ (source place) to the soil of $\mathrm{T}_{2}$. Thus, AMF were also observed in the inner cortical cells of roots in both treatment plants $\left(\mathrm{T}_{1}\right.$, and $\left.\mathrm{T}_{2}\right)$. AMF extraradical hyphal length is estimated, it is widely in the field range [43]. One of the highest estimates is $111 \mathrm{~m} / \mathrm{cm}^{3}$ of soil for a prairie community, for which a hyphal dry weight of less than $0.5 \mathrm{mg} / \mathrm{g}$ is calculated [44].

\subsection{Mineral of SGP}

\subsection{1. $\mathrm{NO}_{3}^{-}$Level}

$\mathrm{NO}_{3}^{-}$level was the most important contributing parameter, which was signifi- 
cantly marked in conventionally grown SGP and treatments. The level of $\mathrm{NO}_{3}^{-}$ of all treatments was approximately 16 times lower than the conventionally (chemical based farming) grown SGP (Figure 7). Average $\mathrm{NO}_{3}^{-}$level $(\mathrm{mg} / \mathrm{L})$ of different treatments was recorded in the order: Conventional (313) $>\mathrm{C}(20), \mathrm{T}_{1}$ (20) $>T_{2}(15), T_{3}(15)$. Several researchers have revealed that the reason for the high gastric cancer incidence in the Far East may lie in the consumption of specific foods that are high in nitrates [45].

\subsection{2. $\mathrm{K}^{+}$, and $\mathrm{Ca}^{2+}$ Level}

$\mathrm{K}^{+}$, and $\mathrm{Ca}^{2+}$ level of SGP were significantly influenced by different treatments. $\mathrm{K}^{+}$, and $\mathrm{Ca}^{2+}$ of SGP of different treatments were in the order: $\mathrm{T}_{1}>\mathrm{T}_{2}>\mathrm{T}_{3}>\mathrm{C}>$ Conventional, and $\mathrm{T}_{1}>\mathrm{T}_{2}>\mathrm{T}_{3}>\mathrm{C}>$ Conventional, respectively. The highest level of $\mathrm{K}^{+}$, and $\mathrm{Ca}^{2+}$ was 5389 , and $537 \mathrm{mg} / \mathrm{L}$ recorded at $\mathrm{T}_{1}$ (Figure 8). Several

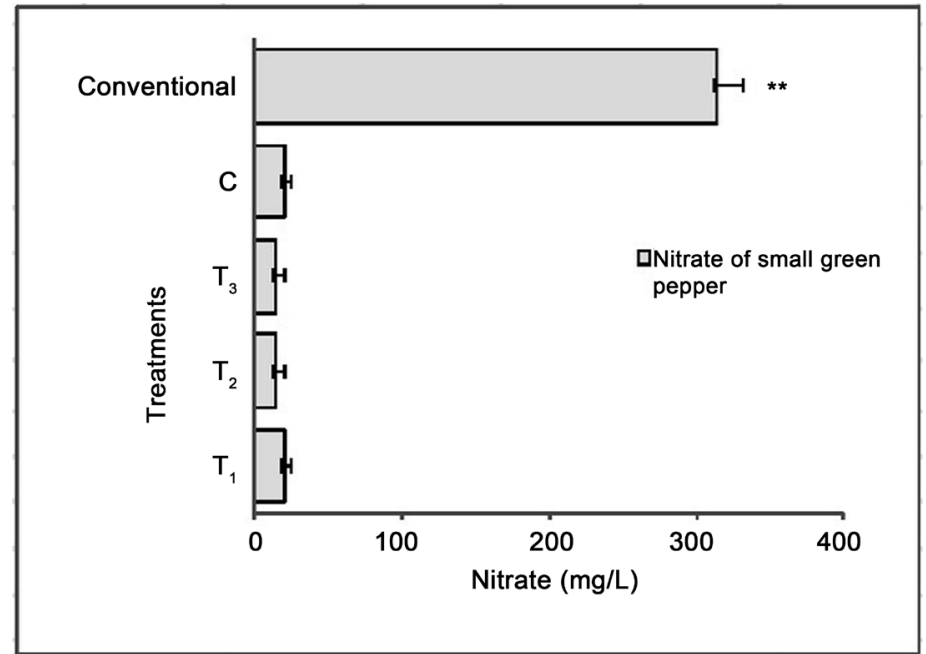

Figure 7. The effect of different treatments on the $\mathrm{NO}_{3}^{-}$level of small green pepper. Significant differences are indicated by asterisks $\left({ }^{*} P<0.01\right)$, horizontal lines represent $\mathrm{SE}$.

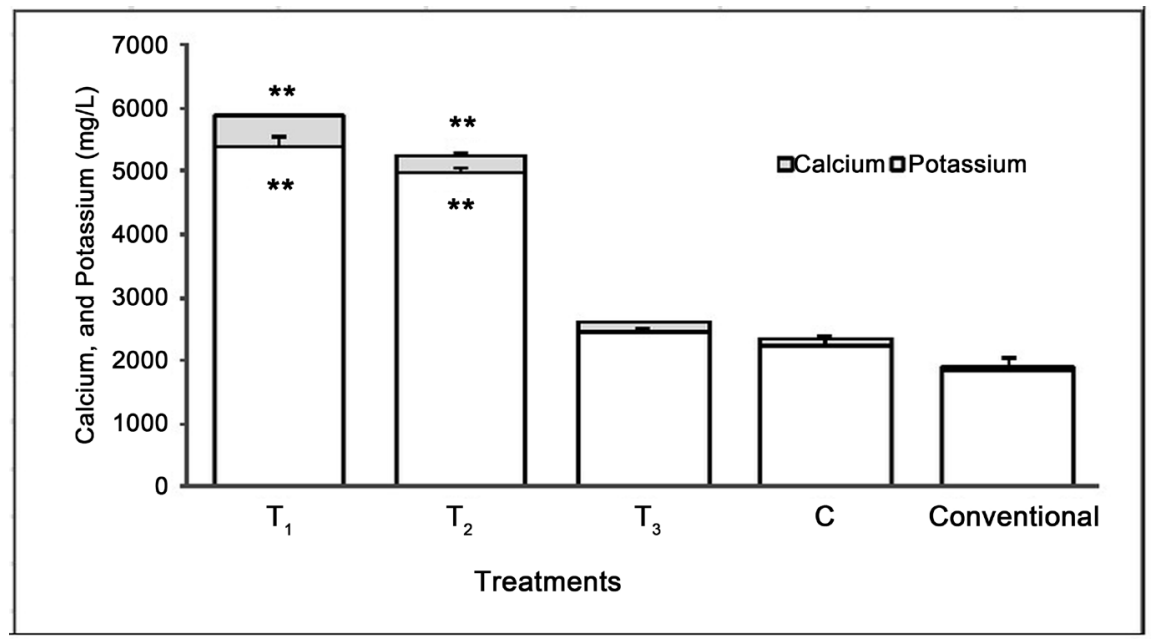

Figure 8. The effect of different treatments on the $\mathrm{K}^{+}$and $\mathrm{Ca}^{2+}$ levels of small green pepper. Significant differences are indicated by asterisks $\left({ }^{\star *} P<0.01\right)$, vertical lines represent $\mathrm{SE}$. 
researchers have shown that the diets low in potassium increase risk of hypertension, stroke and cardiovascular disease [46] and low calcium intake over time, medication interactions that may decrease dietary calcium absorption, and the underlying chronic disease osteoporosis which changes bone formation and strength [47] [48].

\section{Discussion}

Wood and bamboo are rich carbon sources in nature. The chemical composition of wood differs from species to species, but it is approximately $50 \%$ carbon, $42 \%$ oxygen, $6 \%$ hydrogen, $1 \%$ nitrogen, and $1 \%$ other elements (mainly calcium, potassium, sodium, magnesium, iron, and manganese) by weight [49]. The chemical composition of bamboo is similar to that of wood [50]. Carbon of wood and bamboo is one of the most useful and active agents introducing suitable chemical, physical and microbiological changes in the soil, and thereby directly increasing the fertility and crop productivity of the soil. This organic carbon is the basis of soil fertility; it promotes the structure, biological and physical health of soil. Several researchers have revealed that the application of high Carbon: Nitrogen material increases nitrogen fixation in tropical agricultural field and enriches the formation of top layer soil [17]. In the present work, the growth and yield of SGP showed the great variations between $\mathrm{T}_{1}$ (carbon sources, and $\mathrm{AMF}$ and GF) and $\mathrm{T}_{3}$ (only $\mathrm{AMF}$ and GF) treatment plots whereas the same amount of AMF and GF was given at the both treatments $\left(\mathrm{T}_{1}\right.$, and $\left.\mathrm{T}_{3}\right)$. The experimental results indicate the importance of carbon sources at $\mathrm{T}_{1}$ treatment. The highest yield was $1.22 \mathrm{~kg} / \mathrm{m}^{2}$ produced at $T_{1}$, which was, approximately, 4 times higher than $\mathrm{T}_{2}, \mathrm{AMF}$ and GF were the basic differences concerning $\mathrm{T}_{1}$, and $\mathrm{T}_{2}$. It must be pointed out that the AMF were observed in the inner cortical cells of roots at the both treatments $\left(\mathrm{T}_{1}\right.$, and $\left.\mathrm{T}_{2}\right)$. Whereas, AMF and GF were used only in $\mathrm{T}_{1}$, AMF spread to a large area from the soil of $\mathrm{T}_{1}$ (source place) to the soil of $\mathrm{T}_{2}$. Several researchers have revealed that the rootexternal mycelium spreads several centimeters away from root surfaces into the soil, many metres of fungal hyphae may be produced per gram of soil. This result significantly increases surface area for plant nutrient absorption [44]. Although there is a marked diversity among AM fungal communities belowground, depending on plant species diversity, soil type, and season, or a combination of these factors [51]. AMF influenced significantly the shoot length, and the stem diameter of plants at $\mathrm{T}_{1}$. The stem diameter $(\mathrm{cm})$ of plants was in the order: $\mathrm{T}_{1}(2.00)>\mathrm{T}_{2}(1.02)>\mathrm{C}(0.26)>\mathrm{T}_{3}(0.25)$, and average shoot length $(\mathrm{cm})$ for different treatments was in the order: $\mathrm{T}_{1}(59.00)>\mathrm{T}_{2}(43.25)>\mathrm{T}_{3}(20.00)>C$ (17.25). AM symbiosis can rise the leaf area, and delays senescence [52] [53]. AMF can increase $\mathrm{P}$ absorption in pepper, and proliferate the shoot and root dry weight [54]. In the present work, weeds (meadow grass, couch grass, horsetail, nettle, chickweed, ground elder, etc.) were put in the one furrow (combined furrow of $\mathrm{T}_{1}$ and $\mathrm{T}_{2}$ ) to add organic matter in the soil. Meanwhile, AMF accele- 
rate the organic matter decomposition rates [55] and deliver some raw materials, which raise $\mathrm{CO}_{2}$ concentration in micro circumstance [56] [57] and assist soil carbon turnover in the agro-or grassland via $\mathrm{CO}_{2}$ stimulation effects [58]. According to the result of this experiment, AMF played a dynamic role in the presence of carbon and organic materials on the growth, development, and yield of $\mathrm{T}_{1}$ plants. Plenty of carbon and organic materials, and small amounts of AMF and GF were applied at $T_{1}$, whereas AMF and GF at $T_{2}$ were not applied at the transplanting date of SGP. The AM symbiosis is the association between fungi of the order Glomales (Zygomycetes) and the roots of terrestrial plants [42]. AMF growth can result in enhance decomposition of complex organic material and alter plant $\mathrm{N}$ uptake [59] [60]. GF are endophytic fungi, a number of authors have documented that the presence of endophytic fungi provide a protection of the plant hosts against insect herbivore [61], parasitic nematodes [62] [63], and plant pathogens [64] [65]. In the present study, mineral concentration of soil was significantly enhanced from the before transplanting time to the harvesting time at $\mathrm{T}_{1}$ due to the presence of carbon, organic and fungal sources. Several researchers have shown that the AMF increase soil carbon sequestration in the coalfields in northwest China and AMF are favorable to ecosystems through assisting carbon conservation in coalfield soils [66]. AMF inoculation deserves a series changes in soil respiration, photosynthesis, and carbon storage via close symbiosis with host plants, leading to increase carbon production and enrich nutritional status against the harmful effects [67]-[72]. The highest soil mineral concentration was $6.83(\mathrm{~N}), 16.30(\mathrm{P})$, and $26.66(\mathrm{~K}) \mathrm{mg} / 100 \mathrm{~g}$ analyzed at harvesting time in the $T_{1}$ soil. The soil mineral concentration gradually increased after passing of a certain time. The application of carbon, organic, and fungal sources improved soil fertility at after planting period. Several researchers have revealed that the AM symbiosis is being recognized to influence soil development [73] [74]. Mycorrhizal hyphae adhere to soil particles, which would improve contact with the soil solution, and can access smaller pores than plant roots and root hairs [75]. AM association allows plants to explore larger volumes of soil to absorb more water and nutrients uptake and transport, and increases absorption of immobile mineral elements such as phosphorus, provides resistance to soil pathogens and drought, and improves water-use efficiency [76]. In the present study, integrated application of carbon and organic sources along with minor amounts of fungal sources not only influenced the growth and production of SGP, but also increased the soil fertility and assured agricultural sustainability. Another important feature of all treatments is that $\mathrm{NO}_{3}^{-}$level was significantly marked at the treatments and conventionally grown SGP. It was approximately 18 times lower than the conventional. Based on the data, $\mathrm{K}^{+}$and $\mathrm{Ca}^{2+}$ level showed the great variation between treatments $\left(\mathrm{T}_{1}\right.$, and $\left.\mathrm{T}_{2}\right)$, and conventionally grown SGP, which indicates the importance of integrated application of carbon, organic and fungal sources $\left(\mathrm{T}_{1}\right.$, and $\left.\mathrm{T}_{2}\right)$. High level of nitrate in the crop has been implicated to cause bladder, ovarian, stomach, and liver cancers 
for human body [77]. Excess nitrogen of chemical based farming reduces carbohydrate synthesis, lowers resistance to diseases (rust and downy mildew), lowers resistance to insect, and reduces the biological value of plant protein [78].

\section{Conclusion}

Plants and microorganisms have been coexisting for hundreds of millions of years. Plants conserve a complex interaction with their rhizospheric populations, which is essential for nutrient assimilation, soil development, and activation of defense mechanisms. In the present work, this beneficial interaction is sustainable. SGP and AMF can communicate with each other through the support of slowly degradable wood and bamboo wastes. According to the result of this experiment, the application of carbon, organic, and fungal sources at $T_{1}$ (wood wastes + bamboo wastes + cut weeds $+\mathrm{AMF}+\mathrm{GF}$ ) obtained high productivity of SGP, and enhanced plant growth, soil mineral, and AMF activity. The yield was 400 times higher than that of control. Another distinctive result was that the $\mathrm{NO}_{3}^{-}$level of all SGP was extremely lower than the conventionally grown SGP. The application of rich carbon sources along with fungal and organic sources $\left(T_{1}\right)$ creates the ideal soil environment, which is suitable for plant growth and development, and increases the populations and diversity of soil organisms. Constructed soil biodiversity does not allow exclusive propagations of harmful pathogens and pests. AMF and GF of $\mathrm{T}_{1}$ influence both plant and soil functions, and mediate their interactions between above and belowground events. This study suggests that application of carbon, organic, and fungal sources has a potential to be innovative agricultural materials for the next generation sustainable agriculture.

\section{References}

[1] U.S. News and World Report (2008) The Toxic Consequences of the Green Revolution.

[2] Pingali, P.L. (2012) Green Revolution: Impacts, Limits, and the Path Ahead. Proceedings of the National Academy of Sciences of the United States of America, 109, 12302-12308. https://doi.org/10.1073/pnas.0912953109

[3] FAO (1996) World Food Summit. FAO, Rome. http://www.fao.org/docrep/003/w2612e/w2612e06a.htm

[4] Sinha, R.K., Sunil, H., Dalsukhbhai, V. and Krunalkumar, C. (2009) The Concept of Sustainable Agriculture: An Issue of Food Safety and Security for People, Economic Prosperity for the Farmers and Ecological Security for the Nations. American-Eurasian Journal of Agricultural \& Environmental Sciences, 5, 1-55. http://www.idosi.org/aejaes/aejaes5(S).htm

[5] National Research Council (1989) Alternative Agriculture. National Academy Press, Washington DC.

[6] FAO (2009) Report of the FAO Expert Meeting on How to Feed the World in 2050. FAO, Rome.

[7] Marini-Bettòlo, G.B. (1987) Scientific Research and the Challenge of Agriculture in 
the Tropics. Developments in Agricultural and Managed Forest Ecology, 19, 7-10. https://doi.org/10.1016/B978-0-444-98927-7.50007-0

[8] Peggy, B. (2000) Agriculture in the New Millennium; Bradley Hydroponics. Oregon.

[9] FAO (2001) Food Security and the Environment, Fact Sheet Prepared for the World Food Summit. FAO, Rome.

[10] FAO (2004) The State of the Food and Agriculture 2003-2004. FAO Publication, Rome.

[11] Horrigan, L., Lawrence, R.S. and Walker, P. (2002) How Sustainable Agriculture Can Address the Environmental and Human Health Harms of Industrial Agriculture. Environmental Health Perspectives, 110, 445-456.

[12] Sinha, R.K. (2008) Organic Farming: An Economic Solution for Food Safety and Environmental Security. Green Farming-International Journal of Agricultural Sciences, 1, 42-49.

[13] Verena, S., Navin, R. and Jonathan, A.F. (2012) Comparing the Yields of Organic and Conventional Agriculture. Nature, 485, 229-232. https://doi.org/10.1038/nature11069

[14] McIntyre, B.D., Herren, H.R., Wakhungu, J. and Watson, R.T. (2009) International Assessment of Agricultural Knowledge, Science and Technology for Development. Global Report, Island.

[15] De Schutter, O. (2010) Report Submitted by the Special Rapporteur on the Right to Food, United Nations.

[16] Trewavas, A. (2001) Urban Myths of Organic Farming. Nature, 410, 409-410. https://doi.org/10.1038/35068639

[17] Oda, M., Tamura, K., Nakatsuka, H., Nakata, M. and Hayashi, Y. (2014) Application of High Carbon: Nitrogen Material Enhanced the Formation of the Soil A Horizon and Nitrogen Fixation in a Tropical Agricultural Field. Agricultural Sciences, 5, 1172-1181. https://doi.org/10.4236/as.2014.512127

[18] Miller, R. and Jastrow, J. (2000) Mycorrhizal Fungi Influence Soil Structure. In: Kapulnik, Y. and Douds, D.D., Eds., Arbuscular Mycorrhizas: Physiology and Function, Springer, Dordrecht, 3-18. https://doi.org/10.1007/978-94-017-0776-3_1

[19] Pretty, J. and Bharucha, Z.P. (2014) Sustainable Intensification in Agricultural Systems. Annals of Botany, 114, 1571-1596. https://doi.org/10.1093/aob/mcu205

[20] Basic Act for the Promotion of Biomass Utilization (2016) The Ministry of Agriculture, Forestry and Fisheries in Japan. 9.

[21] Phillips, J.M. and Hayman, D.S. (1970) Improved Procedures for Clearing Roots and Staining Parasitic and Vesicular-Arbuscular Mycorrhizal Fungi for Rapid Assessment of Infection. Transactions of the British Mycological Society, 55, 158-161. https://doi.org/10.1016/S0007-1536(70)80110-3

[22] Van der Heijden, M.G.A., Klironomos, J.N., Ursic, M., Moutoglis, P., Streitwolf-Engel, R., Boller, T., et al. (1998) Mycorrhizal Fungal Diversity Determines Plant Biodiversity, Ecosystem Variability and Productivity. Nature, 396, 69-72. https://doi.org/10.1038/23932

[23] Iqbal, M. and Ashraf, M. (2013) Alleviation of Salinity-Induced Perturbations in Ionic and Hormonal Concentrations in Spring Wheat through Seed Preconditioning in Synthetic Auxins. Acta Physiologiae Plantarum, 35, 1093-1112.

https://doi.org/10.1007/s11738-012-1147-z 
[24] Smith, S.E. and Read, D.J. (1997) Mycorrhizal Symbiosis. Academic, London.

[25] Rivera, E.L. and Guerrero, E. (1998) Ciclaje directo de nutrientes a través de endomicorriza. Un complemento del proceso de mineralización? In: Congres Mondial de Science du Sol, Montpellier, France.

[26] Aristizábal, C., Rivera, E.L. and Janos, D.P. (2004) Arbuscular Mycorrhizal Fungi Colonize Decomposing Leaves of Myrica parvifolia, M. pubescens and Paepalanthus sp. Mycorrhiza, 14, 221-228. https://doi.org/10.1007/s00572-003-0259-0

[27] Leifheit, E.F., Veresoglou, S.D., Lehmann, A., Morris, E.K. and Rillig, M.C. (2014) Multiple Factors Influence the Role of Arbuscular Mycorrhizal Fungi in Soil Aggregation-A Meta-Analysis. Plant and Soil, 374, 523-537. https://doi.org/10.1007/s11104-013-1899-2

[28] Leifheit, E.F., Verbruggen, E. and Rillig, M.C. (2015) Arbuscular Mycorrhizal Fungi Reduce Decomposition of Woody Plant Litter While Increasing Soil Aggregation. Soil Biology and Biochemistry, 81, 323-328. https://doi.org/10.1016/j.soilbio.2014.12.003

[29] Rillig, M.C., Aguilar-Trigueros, C.A., Bergmann, J., Verbruggen, E., Veresoglou, S. D. and Lehmann, A. (2015) Plant Root and Mycorrhizal Fungal Traits for Understanding Soil Aggregation. New Phytologist, 205, 1385-1388.

https://doi.org/10.1111/nph.13045

[30] Gerdemann, J.W., Torrey, J.G. and Clarkson, D.T. (1975) Vesicular-Arbuscular Mycorrhiza. Academic Press, London, 575-591.

[31] Hayman, D.S. (1982) Influence of Soils and Fertility on the Activity and Survival of Arbuscular Mycorrhizal Fungi. Phytopathology, 72, 1119-1125.

[32] Newsham, K.K., Fitter, A.H. and Watkinson, A.R. (1994) Root Pathogenic and Arbuscular Mycorrhizal Fungi Determine Fecundity of Asymptomatic Plants in the Field. Journal of Ecology, 82, 805-814.

[33] Tinker, P.B. and Gildon, A. (1983) Mycorrhizal Fungi and Ion Uptake. In: Robb, D.A., Ed., Metals and Micronutrients: Uptake and Utilization by Plants, Academic Press, London, 21-32. https://doi.org/10.1016/B978-0-12-589580-4.50008-0

[34] Manjunath, A. and Habte, M. (1988) Development of Vesicular-Arbuscular Mycorrhizal Infection and the Uptake of Immobile Nutrients in Leucaena leucocephala. Plant and Soil, 106, 97-103. https://doi.org/10.1007/BF02371200

[35] Pacovsky, R.S. (1986) Micronutrient Uptake and Distribution in Mycorrhizal or Phosphorus-Fertilized Soybeans. Plant and Soil, 95, 379-388. https://doi.org/10.1007/BF02374618

[36] Mohammad, A. and Mittra, B. (2013) Effects of Inoculation with Stress-Adapted Arbuscular Mycorrhizal Fungus Glomus deserticolaon Growth of Solanum melogena L. and Sorghum sudanese Staph. Seedlings under Salinity and Heavy Metal Stress Conditions. Archives of Agronomy and Soil Science, 59, 173-183. https://doi.org/10.1080/03650340.2011.610029

[37] Olsson, P.A., Thingstrup, I., Jakobsen, I. and Bååth, E. (1999) Estimation of the Biomass of Arbuscular Mycorrhizal Fungi in a Linseed field. Soil Biology and Biochemistry, 31, 1879-1887. https://doi.org/10.1016/s0038-0717(99)00119-4

[38] Grace, E.J., Smith, F.A. and Smith, S.E. (2009) Deciphering the Arbuscular Mycorrhizal Pathway of P Uptake in Non-Responsive Plant Species. In: Azcón-Aguilar, C., Barea, J., Gianinazzi, S. and Gianinazzi-Pearson, V., Eds., Mycorrhizas-Functional Processes and Ecological Impact, Springer, Berlin, Heidelberg, 89-106.

[39] Atul-Nayyar, A., Hamel, C., Hanson, K. and Germida, J. (2009) The Arbuscular 
Mycorrhizal Symbiosis Links N Mineralization to Plant Demand. Mycorrhiza, 19, 239-246. https://doi.org/10.1007/s00572-008-0215-0

[40] Silveira, A.P.D. and Freitas, S.S. (2007) Microbiota do Solo e Qualidade Ambiental. Instituto Agronômico, Campinas.

[41] Gang, W., Wei, Z.K., Wang, Y.X., Chu, L.Y. and Shao, H.B. (2007) The Mutual Responses of Higher Plants to Environment: Physiological and Microbiological Aspects. Colloids and Surfaces B: Biointerfaces, 59, 113-119.

https://doi.org/10.1016/j.colsurfb.2007.05.003

[42] Harley, J.L. and Smith, S.E. (1983) Mycorrhizal Symbiosis. Academic Press, London and New York.

[43] Rillig, M.C. and Allen, M.F. (1999) What Is the Role of Arbuscular Mycorrhizal Fungi in Plant to Ecosystem Responses to Elevated Atmospheric $\mathrm{CO}_{2}$. Mycorrhiza, 9, 1-8. https://doi.org/10.1007/s005720050257

[44] Miller, R.M., Reinhardt, D.R. and Jastrow, J.D. (1995) External Hyphal Production of Vesicular-Arbuscular Mycorrhizal Fungi in Pasture and Tallgrass Prairie Communities. Oecologia, 103, 17-23. https://doi.org/10.1007/BF00328420

[45] Duncan, C., Li, H., Dykhuizen, R., Frazer, R., Johnston, P. and MacKnight, G. (1997) Protection against Oral and Gastrointestinal Diseases: Importance of Dietary Nitrate Intake, Oral Nitrate Reduction and Enterosalivary Nitrate Circulation. Comparative Biochemistry and Physiology Part A: Physiology, 118, 939-948. https://doi.org/10.1016/S0300-9629(97)00023-6

[46] D’Elia, L., Barba, G., Cappuccio, F.P. and Strazzullo, P. (2011) Potassium Intake, Stroke, and Cardiovascular Disease: A Meta-Analysis of Prospective Studies. Journal of the American College of Cardiology, 57, 1210-1219. https://doi.org/10.1016/j.jacc.2010.09.070

[47] National Institutes of Health (US) (2013) Dietary Supplement Fact Sheet: Calcium. National Institutes of Health, USA. https://ods.od.nih.gov/factsheets/Calcium/HealthProfessional/

[48] Institute of Medicine Standing Committee on the Scientific Evaluation of Dietary Reference Intakes (US) (1997) Dietary Reference Intakes for Calcium, Phosphorus, Magnesium, Vitamin D, and Fluoride. National Academies Press, Washington DC. https://www.ncbi.nlm.nih.gov/books/NBK109825/

[49] Jean-pierre, B., Claude, H. and Jérôme, M. (1996) Mémotech Bois et Matériaux Associés. Paris Éditions Casteilla, 22.

[50] Higuchi, T. (1957) Biochemical Studies of Lignin Formation. III. Physiologia Plantarum, 10, 633-648. https://doi.org/10.1111/j.1399-3054.1957.tb06971.x

[51] Smith, S.E. and Smith, F.A. (2012) Fresh Perspectives on the Roles of Arbuscular Mycorrhizal Fungi in Plant Nutrition and Growth. Mycologia, 104, 1-13. https://doi.org/10.3852/11-229

[52] Beltrano, J., Ronco, M.G., Salerno, M.I., Ruscitti, M. and Peluso, O. (2003) Respuesta de Planta de Trigo (Triticum aestivum L.) Micorrizadas en Situaciones de Déficit Hídrico y de Rehidratación del Suelo. Revista de Ciencia y Tecnología, 8 , 1-7.

[53] Beltrano, J. and Ronco, M. (2008) Improved Tolerance of Wheat Plants (Triticum aestivum L.) to Drought Stress and Rewatering by the Arbuscular Mycorrhizal Fungus Glomus claroideum: Effect on Growth and Cell Membrane Stability. Brazilian Journal of Plant Physiology, 20, 29-37. https://doi.org/10.1590/S1677-04202008000100004 
[54] Davies Jr., F., Olalde-Portugal, V., Alvarado, M., Escamilla, H., Ferrera-Cerrato, R. and Espinosa, J. (2000) Alleviating Phosphorus Stress of Chile Ancho Pepper (Capsicum annuum L. "San Luis") by Arbuscular Mycorrhizal Inoculation. The Journal of Horticultural Science and Biotechnology, 75, 655-661. https://doi.org/10.1080/14620316.2000.11511303

[55] Zhang, J., et al. (2015) Glomalin-Related Soil Protein Responses to Elevated $\mathrm{CO}_{2}$ and Nitrogen Addition in a Subtropical Forest: Potential Consequences for Soil Carbon Accumulation. Soil Biology and Biochemistry, 83, 142-149.

https://doi.org/10.1016/j.soilbio.2015.01.023

[56] Wang, X.R., et al. (2010) Effect of Co-Inoculation with Arbuscular Mycorrhzial Fungi and Rhizobia on Soybean Growth as Related to Root Architecture and Availability of N and P. Mycorrhiza, 21, 173-181.

https://doi.org/10.1007/s00572-010-0319-1

[57] Cheng, L., et al. (2012) Arbuscular Mycorrhizal Fungi Increase Organic Carbon Decomposition under Elevated $\mathrm{CO}_{2}$. Science, 337, 1084-1087.

https://doi.org/10.1126/science.1224304

[58] Van Groenigen, K.J., Osenberg, C.W. and Hungate, B.A. (2011) Increased Soil Emissions of Potent Greenhouse Gases under Increased Atmospheric $\mathrm{CO}_{2}$. Nature, 475, 214-216. https://doi.org/10.1038/nature10176

[59] Hodge, A. and Fitter, A.H. (2010) Substantial Nitrogen Acquisition by Arbuscular Mycorrhizal Fungi from Organic Material has Implications for N Cycling. Proceedings of the National Academy of Sciences of the United States of America, 107, 13754-13759. https://doi.org/10.1073/pnas.1005874107

[60] Hodge, A., Campbell, C.D. and Fitter, A.H. (2001) An Arbuscular Mycorrhizal Fungus Accelerates Decomposition and Acquires Nitrogen Directly from Organic Material. Nature, 413, 297-299. https://doi.org/10.1038/35095041

[61] Clement, S.L., Elberson, L.R., Bosque-Pérez, N.A. and Schotzko, D.J. (2005) Detrimental and Neutral Effects of Wild Barley-Neotyphodium Fungal Endophyte Associations on Insect Survival. Entomologia Experimentalis et Applicata, 114, 119-125. https://doi.org/10.1111/j.1570-7458.2005.00236.x

[62] Nur, A. (1994) Untersuchungen über die Bedeutung endophytischer Pilze für die biologische Bekämpfung des wandernden Endoparasiten Radopholus similis (Cobb) Thorne an Bananen. PhD-Thesis, Bonn University, Bonn, 112.

[63] Elmi, A.A., West, C.P., Robbins, R.T. and Kirpatrick, T.L. (2000) Endophyte Effects on Reproduction of a Root-Knot Nematode (Meloidogyne marylandi) and Osmotic Adjustment in Tall Fescue. Grass and Forage Science, 55, 166-172. https://doi.org/10.1046/j.1365-2494.2000.00210.x

[64] Dingle, J. and McGee, P.A. (2003) Some Endophytic Fungi Reduce the Density of Pustules of Puccinia recondita f. sp. tritici in Wheat. Mycological Research, 107, 310-316. https://doi.org/10.1017/S0953756203007512

[65] Wiclow, D.T., Roth, S., Deyrup, S.T. and Gloer, J.B. (2005) A Protective Endophyte of Maize: Acremonium zeae Antibiotics Inhibitory to Aspergillus flavus and Fusarium verticillioides. Mycological Research, 109, 610-618. https://doi.org/10.1017/S0953756205002820

[66] Wang, Z.-G., Bi, L.-Y., Jiang, B., Zhakypbek, Y., Peng, S., Liu, W. and Liu, H. (2016) Arbuscular Mycorrhizal Fungi Enhance Soil Carbon Sequestration in the Coalfields, Northwest China. Scientific Reports, 6, Article No. 34336.

[67] Vicca, S., et al. (2009) Arbuscular Mycorrhizal Fungi May Mitigate the Influence of 
a Joint Rise of Temperature and Atmosphere $\mathrm{CO}_{2}$ on Soil Respiration in Grasslands. International Journal of Ecology, 2009, Article ID: 209768. https://doi.org/10.1155/2009/209768

[68] Kaschuk, G., et al. (2009) Are the Rates of Photosynthesis Stimulated by the Catbon Sink Strength of Rhizobial and Arbuscular Mycorrhizal Symbiosis? Soil Biology and Biochemistry, 41, 1233-1244. https://doi.org/10.1016/j.soilbio.2009.03.005

[69] Tian, Y.H., et al. (2013) Synergistic Effect of Colonization with Arbuscular Mycorrhizal Fungi Improves Growth and Drought Tolerance of Plukenetia volubilis Seedlings. Acta Physiologiae Plantarum, 35, 687-696. https://doi.org/10.1007/s11738-012-1109-5

[70] Cavagnaro, T.R., et al. (2008) Growth, Nutrition, and Soil Respiration of a Mycorrhiza-Defective Tomato Mutant and Its Mycorrhizal Wild-Type Progenitor. Functional Plant Biology, 35, 228-235. https://doi.org/10.1071/FP07281

[71] Moyano, F.E., Kutsch, W.L. and Schulze, E.D. (2007) Response of Mycorrhizal, Rhi zosphere and Soil Basal Respiration to Temperature and Photosynthesis in a Barley Field. Soil Biology and Biochemistry, 39, 843-853.

https://doi.org/10.1016/j.soilbio.2006.10.001

[72] Verbruggen, E., et al. (2013) Arbuscular Mycorrhizal Fungi-Short-Term Liability but Long-Term Benefits for Soil Carbon Storage? New Phytologist, 197, 366-368. https://doi.org/10.1111/nph.12079

[73] Miller, R.M. and Jastrow, J.D. (1992) The Role of Mycorrhizal Fungi in Soil Conservation. In: Bethlenfalvay, G.J. and Linderman, R.G., Eds., Mycorrhizae in Sustainable Agriculture, ASA Special Publication No. 54, Chap. 2, American Society of Agronomy, Crop Science Society of America, and Soil Science Society of America, Madison, Wisconsin, 29-44.

[74] Schreiner, R.P. and Bethlenfalvay, G.J. (1995) Mycorrhizal Interactions in Sustainable Agriculture. Critical Reviews in Biotechnology, 15, 271-285. https://doi.org/10.3109/07388559509147413

[75] O’Keefe, D.M. and Sylvia, D.M. (1993) Seasonal Dynamics of the Association between Sweet Potato and Vesicular-Arbuscular Mycorrhizal Fungi. Mycorrhiza, 3, 115-122. https://doi.org/10.1007/BF00208919

[76] Al-Karaki, G.N. (2000) Growth of Mycorrhizal Tomato and Mineral Acquisition under Salt Stress. Mycorrhiza, 10, 51-54. https://doi.org/10.1007/s005720000055

[77] Mueller, B.A., Newton, K., Holly, E.A. and Preson-Martin, S. (2001) Residential Water Source and the Risk of Childhood Brain Tumors. Environmental Health Perspectives, 109, 551-556. https://doi.org/10.1289/ehp.01109551

[78] Hornick, S.B. (2010) Nutritional Quality of Crops as Affected by Management Practices.

http://infrc.or.jp/english/KNF_Data_Base_Web/PDF\%20KNF\%20Conf\%20Data/C3 -3-070.pdf 